\section{NSF gets new director}

Almost as soon as John B. Slaughter, the outgoing director of the US National Science Foundation (NSF), the nation's basic research agency, announced that he would leave on 1 November to take up his duties at the University of Maryland, the White House announced his successor. On 3 November Edward A. Knapp assumed his new duties as director.

Knapp, a physicist with degrees from Pomona College and the University of California at Berkeley, had been confirmed in September as assistant director of NSF for mathematical and physical sciences. His entire previous career was with the Los Alamos National Laboratory, where he worked with George A. Keyworth, who is now the President's Science Advisor. Ironically, the White House personnel office made the appointment with despatch while Keyworth, Slaughter and NSF's deputy director Donald Langenberg - who was rumoured as a likely candidate - were out of town.

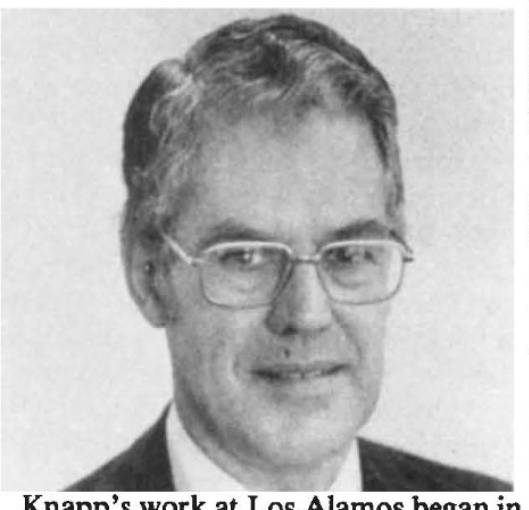

Knapp's work at Los Alamos began in 1958. He worked on controlled thermonuclear research and helped to plan the linear proton accelerator, the Los Alamos Meson Physics Facility (LAMPF). Knapp spent a year at CERN in Geneva, where he worked out a collaborative programme between CERN and Los Alamos. Before coming to Washington Knapp was director of the laboratory's accelerator technology division.

Since Congress is in recess at present, Knapp is assuming his duties without being formally confirmed. Langenberg plans to stay on, although his name is on a list of candidates for the presidency of the University of New Mexico. At the time that Knapp was appointed, there were rumours in Washington of a major conservative housecleaning at NSF, which could not be confirmed. Moreover, the national elections, which seemed to deprive the Reagan Administration of some of its far-right conservative mandate, make such a sweep very unlikely. Deborah Shapley

\title{
French energy
}

\section{Forecasts fall}

In the midst of an appalling economic crisis, the French government is about to be struck another blow with the expected publication this week of an official energy forecast which will lower projected electricity consumption in 1990 by nearly a quarter.

The consequences fall neatly on the coal and nuclear industries, both of them political hot potatoes for a socialist government. Coal and nuclear energy are the dominant power sources in France (producing 24 per cent and 37 per cent of delivered electric power in 1981), excepting hydroelectricity (27 per cent) which, as nearly "free" power, is likely to be untouched by the new forecast. The socialist party has committed itself to support the coal industry - and indeed expand production - but the nuclear lobby is strong and supported vociferously by the powerful research and industry minister, Jean-Pierre Chevènement.

The new figures come from the Commission du Plan, an institution which is both within and to some degree aside from the government. But its pronouncements - broad political and economic plans for the future - are taken seriously. In this case, the "long-term energy" committee of the commission has calculated that electricity consumption will not be 450,000 million $\mathrm{kWh}$ in 1990 as envisaged in the previous (1980) plan, but only 350,000 million $\mathrm{kWh}$, compared with a true consumption in 1980 of 246,000 million $\mathrm{kWh}$. Thus the projected increase has been halved, with a consequent revolution in thinking about power station construction and power sales.

Electricité de France (EDF), which is strongly behind nuclear power, contests the figures and predicts that consumption will be 390,000 million $\mathrm{kWh}$ in 1990 ; but it still admits that there will be overcapacity. EDF argues that surplus electricity can be exported - French electricity is the cheapest in Europe, largely because of government pricing policy - and that the nuclear power industry must build at least two stations a year until 1990 or it will collapse. A successful nuclear industry will lead to nuclear exports later, the argument goes. But if nuclear power station construction continued at the present rate of four stations a year, it is estimated that coal burning for electricity - which makes up half the French coal market - would fall from its present level of 64,000 million $\mathrm{kWh}$ to 32,000 million $\mathrm{kWh}$ in 1985 and even less in 1990

With little union backing for coal (the communist CGT union, which is strong in both the coal and nuclear industry has opted for nuclear energy), and with Chevènement behind nuclear power, it seems likely that the EDF view will be supported, and a substantial nuclear programme maintained, with unpleasant consequences for the socialist party in the French coal districts in the municipal elections in the spring.

Why then are the forecasts falling? The answer is twofold. First, French economic growth is well below target, and seems unlikely to rise before 1985; and second there is growing confidence in the Agency Française pour la Maitrise de l'Energie (AFME), which seems to have had considerable success since its formation earlier this year from a group of disparate bodies concerned with energy conservation and renewable energies.

In 1983, AFME will invest FF 1,200 million ( $£ 100$ million), much of it in investment support grants which will raise a total of FF 20,000 million ( $£ 1,300$ million) in conservation and alternatives next year. The aim is to reach FF 40,000 million $(£ 2,600$ million) a year by 1990 , comparable with the present French investment rate in nuclear power. Some of the seed money is being raised by a tax on petrol at the pump.

By 1990 , AFME is expected to have led to renewables usage of some 12 million tonnes of oil equivalent a year (around 10 per cent of primary energy consumption) with the greatest portion coming from wood and biomass, then from lowtemperature geothermal heat (particularly by better exploitation of sources in the Paris basin) and finally from solar power. But the great saving comes in energy conservation - around 40 million tonnes of oil equivalent a year by 1990 , according to AFME projections, which are broadly accepted by the Commission du Plan.

Robert Walgate

Genetic engineering

\section{Human insulin}

\section{Washington}

The commercial potential of genetic engineering was boosted in the United States on 29 October when the Food and Drug Administration (FDA) gave marketing approval to Humulin, a human insulin made with genetic engineering techniques. Made by Eli Lilly Company, the substance had won approval for marketing in the United Kingdom only a month before (see Nature 23 September, p.293). Although the announcement has symbolic value in the field and in particular for Genentech Inc., the California company that invented it, it will probably not quickly make a material difference to the fortunes of either Genentech or Eli Lilly.

Genetically-engineered human insulin is expected to be almost twice as expensive as the insulins now derived from pigs and cattle, which cost an estimated 26-30 cents per day of treatment. Lilly already has an estimated 85 per cent of the insulin market in the United States, so there is not likely to be a large market for Humulin soon, although the new product has an advantage in the few diabetics who develop an allergy 